Jurnal Perikanan (2021) Volume 11. No. 2 : 259-266

DOI : https://doi.org/10.29303/jp.v10i2.198

\title{
KERAGAMAN BENIH SIDAT DAN SIDAT DEWASA (Anguilla sp.) DI SUNGAI DUMOGA, SULAWESI UTARA
}

\section{DIVERSITY OF SEED EEL AND ADULT EEL (Anguilla sp.) IN DUMOGA RIVER, NORTH SULAWESI}

\author{
Ni Putu Dian Kusuma*1), Endang Yuli Herawati²), Abu Bakar Sambah ${ }^{3)}$ \\ ${ }^{1)}$ Program Studi Teknik Budidaya Perikanan, Politeknik Kelautan dan Perikanan Kupang \\ ${ }^{2}$ Program Studi Budidaya Perairan, Universitas Brawijaya, Malang \\ ${ }^{3)}$ Program Studi Pemanfaatan Sumberdaya Perikanan, Universitas Brawijaya, Malang \\ Jl. Kampung Baru Pelabuhan Ferry Bolok, Kab. Kupang, Provinsi NTT \\ *)alamat korespondensi: ndkbluefin89@gmail.com
}

\begin{abstract}
ABSTRAK
Lokasi pemijahan Anguilla borneensis dan Anguilla celebesensis berada di laut lepas Sulawesi dan Teluk Tomini, lokasi pemijahan Anguilla marmorata dan Anguilla bicolor pacifica berada di bagian barat Pasifik Utara. Tujuan penelitian ini untuk mengetahui informasi keragaman benih sidat dan sidat dewasa di Sungai Dumoga berdasarkan kelimpahan benih sidat dan kematangan gonad sidat dewasa. Spesies sidat terdiri dari $A$. marmorata sebanyak 1.106 ekor, A. bic. pacifica sebanyak 854 ekor dan Anguilla spp sebanyak 291 ekor. Ikan sidat hasil tangkapan dipisahkan berdasarkan bentuk morfologi spesies ikan sidat. Pemisahan hasil tangkapan berdasarkan penciri khusus ikan sidat yakni panjang preanal dan predorsal. Nilai anodorsal terbagi dalam tiga kelompok yaitu $\pm 15,57 \%$ (A. marmorata) $\pm 1,18 \%$ (A. bicolor pacifica) dan $\pm 7,09 \%$ (Anguilla spp.). Nilai meristik $A$. marmorata untuk Tulang Belakang (TB) total 104-106 buah, pre-dorsal TB 17-19 buah, preanal TB 36-39 buah dan ano-dorsal TB 18-20 buah. Nilai meristik A. bicolor pacifica untuk tulang belakang (TB) total 108-112 buah, pre-dorsal TB 32-36 buah, pre-anal TB 32-39 buah dan ano-dorsal TB 0-3 buah. Nilai meristik Anguilla spp untuk tulang belakang (TB) total 100-106 buah, pre-dorsal TB 27-29 buah, pre-anal TB 30-33 buah dan ano-dorsal TB 6-12 buah. Pola pertumbuhan sidat dewasa bersifat allometrik negatif, yakni pertambahan panjang tubuh lebih cepat dibandingkan dengan pertambahan berat tubuh yang lebih lambat. Kondisi sidat dewasa di Sungai Dumoga tidak gemuk karena faktor kondisinya berkisar antara 0,0024-0,0036. Panjang rata-rata sidat dewasa 58.92 cm pada Anguilla marmorata (IKG 1,57$2,90 \%$ ); 54,2cm pada A. bicolor pacifica (IKG 1,27-2,79\%) dan 52,32cm pada Anguilla spp (IKG 0,97-2,50\%).
\end{abstract}

Kata kunci: keragaman, benih sidat, sidat dewasa, sungai dumoga

\begin{abstract}
The spawning sites of Anguilla borneensis and Anguilla celebesensis were in the seas off Sulawesi and the Gulf of Tomini, the spawning sites of Anguilla marmorata and Anguilla bicolor pacifica were in the western part of the North Pacific. The purpose of this study was to find out information on the diversity of eel seeds and adult eels in the Dumoga River based on the abundance of eel seeds and gonad maturity of adult eels. The eel species consisted of 1,106 A. marmorata, A. bic. pacifica as many as 854 tails and Anguilla spp as many as 291 individuals. The caught eel fish were separated based on the morphology of the eel species.
\end{abstract}


Segregation of catches based on special characteristics of eel, namely preanal and predorsal lengths. Anodorsal values were divided into three groups, namely $\pm 15.57 \%$ (A. marmorata); $\pm 1.18 \%$ (A. bicolor pacifica) and $\pm 7.09 \%$ (Anguilla spp.). Meristic values of A. marmorata for spine (TB) total 104-106 units, pre-dorsal TB 17-19, pre-anal TB 36-39 and ano-dorsal TB 18-20. Meristic values of $A$. bicolor pacifica for spine (TB) totaled 108-112, pre-dorsal TB 32-36, pre-anal TB 32-39 and ano-dorsal TB 0-3. Meristic values of Anguilla spp for spinal (TB) totaled 100-106, pre-dorsal TB 27-29, pre-anal TB 30-33 and ano-dorsal TB 6-12. The growth pattern of adult eels is negative allometric, i.e. the body length gains faster than the slower body weight gain. The condition of adult eels in the Dumoga River is not fat because the condition factor ranges from 0.0024-0.0036. The average length of adult eels was $58.92 \mathrm{~cm}$ in Anguilla marmorata (GIC $1.57-2.90 \%$ ); $54.2 \mathrm{~cm}$ in A. bicolor pacifica (ICI 1.27$2.79 \%$ ) and $52.32 \mathrm{~cm}$ in Anguilla spp (ICI 0.97-2.50\%).

Keywords: diversity, eel seeds, adult eels, Dumoga river

\section{PENDAHULUAN}

Sungai Dumoga memiliki potensi perikanan karena dekat dengan lokasi pemijahan sidat (Kusuma, 2016). Lokasi pemijahan A. borneensis dan A. celebesensis berada di laut lepas Sulawesi dan Teluk Tomini, sedangkan lokasi pemijahan A. marmorata dan A. bicolor pacifica berada di bagian barat Pasifik Utara (Sugeha dan Arai, 2010). Potensi perikanan sidat di Sungai Dumoga mendukung kegiatan perikanan secara signifikan bagi pendapatan masyarakat Kabupaten Bolaang Mongondow khususnya nelayan.

Permintaan sidat yang tinggi mengakibatkan terjadinya usaha pembesaran pada budidaya ikan sidat yang selama ini mengandalkan ketersediaan benih di alam (Widyasari, 2013). Benih sidat yang ditangkap di Sungai Dumoga dimanfaatkan oleh Balai Perikanan Budidaya Air Tawar (BPBAT) Tatelu sebagai komoditi usaha pembesaran karena selalu ditemui sepanjang tahun, dengan puncak penangkapan pada bulan MeiOktober (Kusuma, 2018). Melalui penelitian ini akan diketahui informasi keragaman benih sidat dan sidat dewasa di Sungai Dumoga berdasarkan kelimpahan benih sidat dan kematangan gonad sidat dewasa.

\section{METODE PENELITIAN}

Metode yang digunakan dalam penelitian ini adalah metode deskriptif. Sampel ikan penelitian dikoleksi dari 2 lokasi yaitu benih sidat dari muara sungai dan sidat dewasa dari tengah sungai.

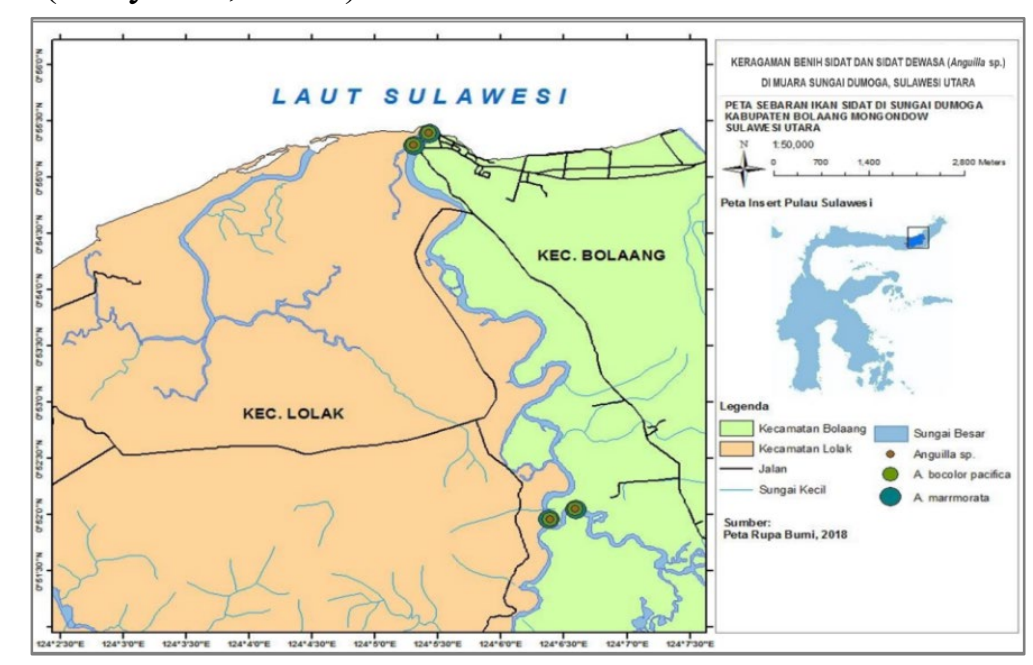

Gambar 1. Lokasi pengambilan sampel sidat 
Tabel 1. Matriks penelitian

\begin{tabular}{|c|c|c|c|c|}
\hline Tujuan & Input & Parameter & Analisis & Output \\
\hline $\begin{array}{l}\text { 1. Mendapatkan } \\
\text { karakter } \\
\text { morfologi, } \\
\text { morfometrik } \\
\text { dan meristik }\end{array}$ & $\begin{array}{l}\text { 1. Sampel } \\
\text { benih } \\
\text { sidat }\end{array}$ & $\begin{array}{l}\text { 1. Morfologi } \\
\text { sidat } \\
\text { 2. Morfometrik } \\
\text { dan meristik } \\
\text { benih sidat }\end{array}$ & 1. Deskriptif & $\begin{array}{l}\text { 1. Karakter morfologi, } \\
\text { morfometrik dan } \\
\text { meristik }\end{array}$ \\
\hline $\begin{array}{l}\text { 2. Mendapatkan } \\
\text { karakteristik } \\
\text { aspek biologi } \\
\text { sidat dewasa }\end{array}$ & $\begin{array}{l}\text { 2. Sampel } \\
\text { sidat } \\
\text { 3. Gonad } \\
\text { ikan } \\
\text { betina }\end{array}$ & $\begin{array}{l}\text { 1. Panjang dan } \\
\text { Berat sidat } \\
\text { 2. Berat gonad } \\
\text { 3. Pertumbuhan } \\
\text { 4. Nisbah } \\
\text { kelamin } \\
\text { 5. Persentase } \\
\text { matang gonac }\end{array}$ & $\begin{array}{l}\text { 1. Perbandingan } \\
\text { Lc dan Lm, } \\
\text { 2. Histologi } \\
\text { 3. Deskriptif } \\
\text { d }\end{array}$ & $\begin{array}{l}\text { 1. Bentuk pertumbuhan } \\
\text { spesies ikan sidat } \\
\text { 2. Hubungan panjang } \\
\text { berat ikan } \\
\text { 3. Reproduksi (TKG, IKG } \\
\text { dan tipe pemijahan) } \\
\text { 4. Ukuran ikan pertama } \\
\text { kali matang gonad (Lm) } \\
\text { 5. Ukuran ikan pertama } \\
\text { kali tertangkap (Lc) }\end{array}$ \\
\hline
\end{tabular}

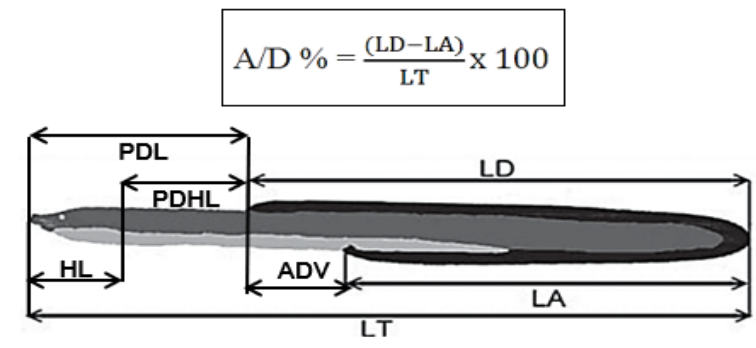

Gambar 2. Pengukuran morfometrik sidat (Modifikasi dari Elie et al., 1982 dalam Serdiati et al., (2013).

$\mathrm{LD}=$ panjang sirip dorsal;

$\mathrm{A}=$ panjang sirip anal;

$\mathrm{LT}=$ panjang total; $\mathrm{HL}=$ panjang kepala; $\mathrm{PDL}=$ panjang predorsal; $\mathrm{PDHL}=$ jarak kepala-pre-dorsal; $\mathrm{ADV}=$ anodorsal vertebra

Pengambilan benih sidat dan sidat dewasa melibatkan partisipasi aktif dari masyarakat nelayan setempat sebagai enumerator. Koordinat lokasi pengambilan sampel direkam menggunakan GPS. Sampling benih sidat dilakukan dengan cara menggunakan alat tangkap "sero" ukuran mata jaring $1 \mathrm{~mm}$. Alat ini dioperasikan sejak benih sidat terlihat memasuki muara sungai sampai tidak

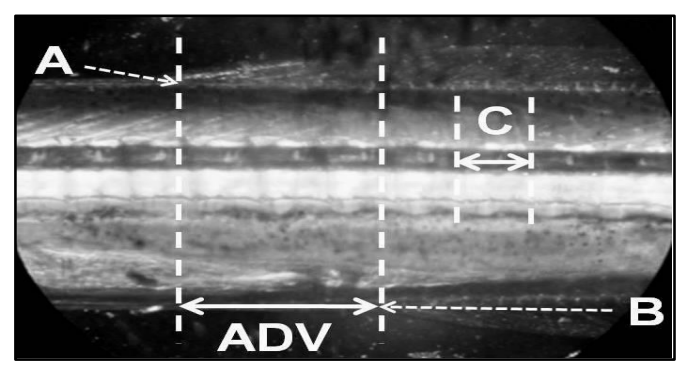

Gambar 3. Pengukuran panjang anodorsal (Modifikasi dari Serdiati et al., 2013). $\mathrm{ADV}=$ panjang anodorsal; $A=$ panjang sirip punggung; $\mathrm{B}=$ pangkal sirip dubur; $\mathrm{C}=1$ buah tulang belakang

terlihat lagi menjelang pagi setiap periode bulan gelap mulai jam 23.00 sampai 03.00 WITA.

Ikan sidat hasil tangkapan dipisahkan berdasarkan bentuk morfologi spesies ikan sidat. Pemisahan hasil tangkapan berdasarkan penciri khusus ikan sidat yakni panjang preanal dan predorsal. Masing-masing spesies sampel ikan sidat difoto menggunakan kamera digital Nikon 
Jurnal Perikanan (2021) Volume 11. No. 2 : 259-266

DOI : https://doi.org/10.29303/jp.v10i2.198

D5200. Sampel ikan dipisahkan kedalam kelompok spesies, kemudian dimasukkan kedalam kotak pendingin yang berisi es, lalu dibawa ke laboratorium untuk proses identifikasi morfologi (morfometrik dan meristik) dan pengukuran karakteristik biologi. Identifikasi contoh ikan sidat dalam kondisi pingsan (menggunakan formalin 15-17,5 ppm).

\section{HASIL}

Kabupaten Bolaang Mongondow adalah salah satu kabupaten di provinsi Sulawesi Utara dengan ibukotanya adalah Lolak, yang berjarak sekitar $200 \mathrm{~km}$ dari kota Manado, ibukota Provinsi Sulawesi Utara. Muara sungai Dumoga yang berhubungan langsung dengan Laut Sulawesi yang diketahui merupakan lokasi pemijahan ikan sidat Anguilla marmorata, Anguilla bicolor pacifica, Anguilla celebensis dan Anguilla borneensis.

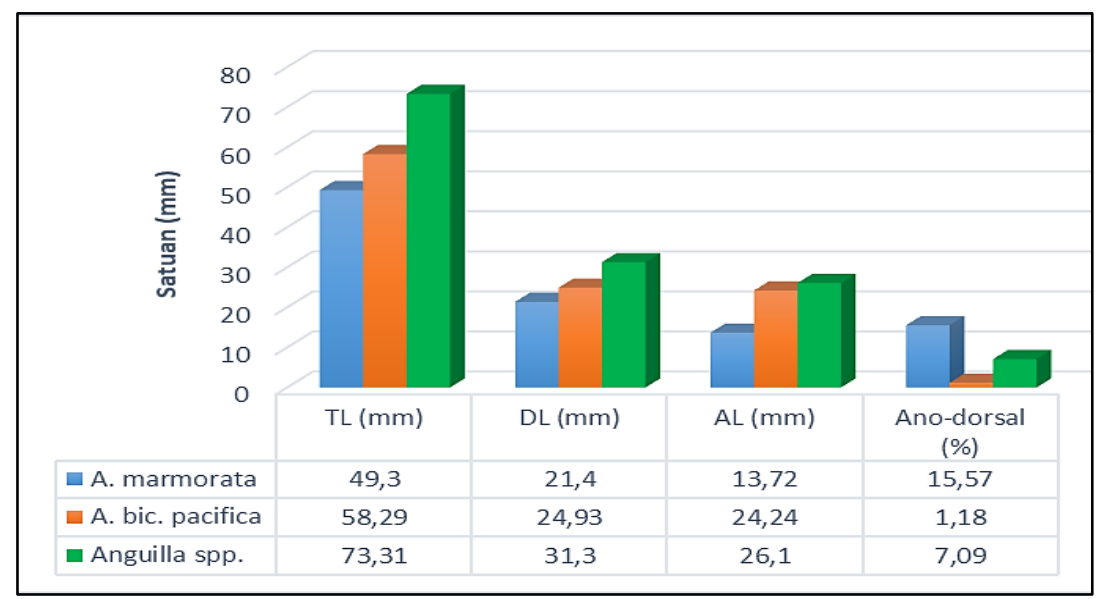

Gambar 4. Pengelompokan benih sidat berdasarkan nilai morfometrik

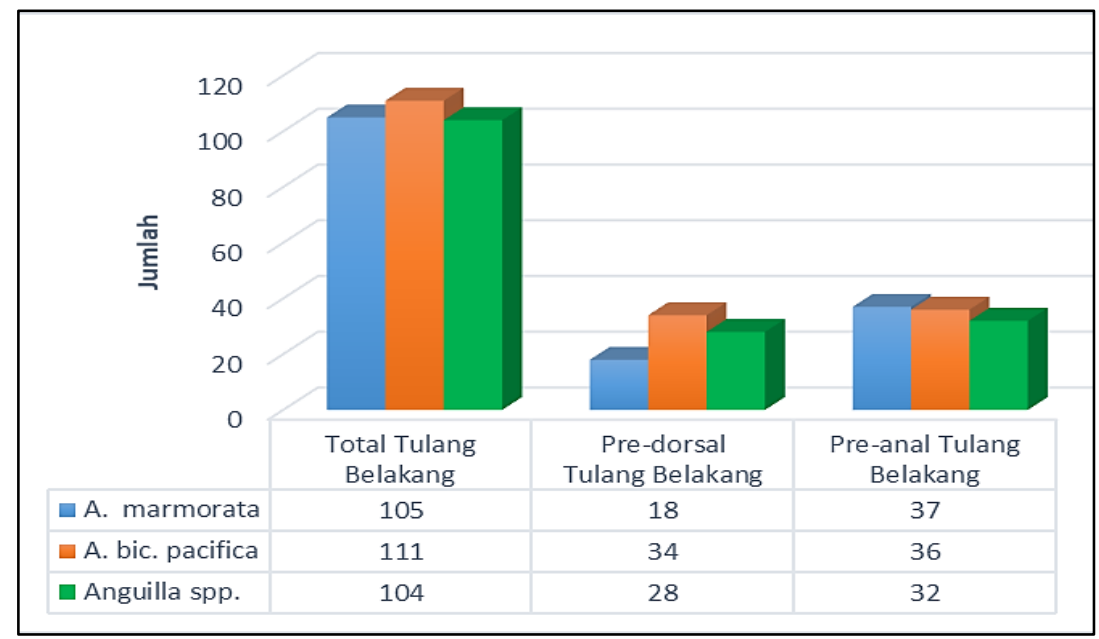

Gambar 5. Pengelompokan benih sidat berdasarkan nilai nilai meristik

Mengacu pada pengelompokan ikan sidat berdasarkan nilai Anodorsal, diketahui jenis sidat yang masuk ke muara Sungai
Dumoga adalah A. marmorata, A. bicolor pacifica dan yang belum teridentifikasi diberi label sebagai Anguilla spp. 
Jurnal Perikanan (2021) Volume 11. No. 2 : 259-266

DOI : https://doi.org/10.29303/jp.v10i2.198
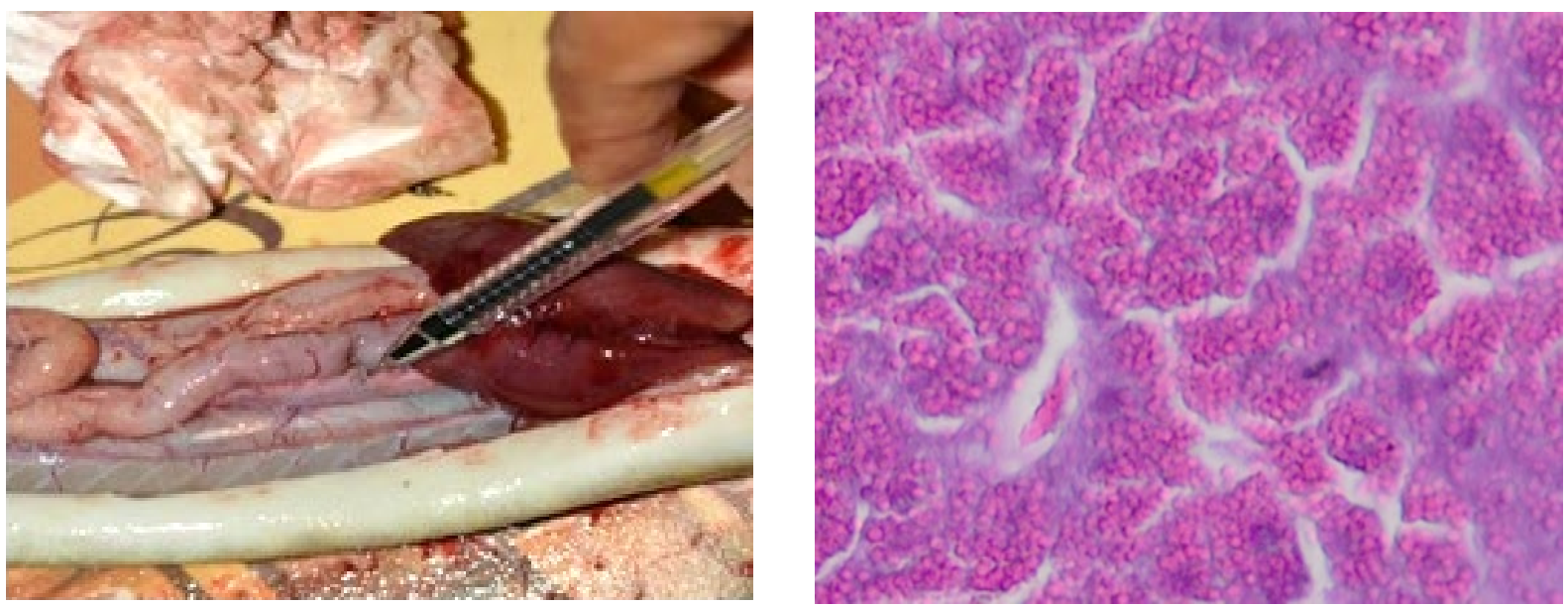

Gambar 6. Kondisi gonad sidat dewasa

Tabel 2. Nilai indeks kematangan gonad (IKG) ikan sidat dewasa

\begin{tabular}{lccc}
\hline \multicolumn{1}{c}{ Parameter } & $\begin{array}{c}\text { Anguilla bicolor } \\
\text { pacifica }\end{array}$ & Anguilla. marmorata & Anguilla spp. \\
\hline Panjang tubuh (cm) & $32-85$ & $37-94$ & $28-73$ \\
Bobot tubuh (gr) & $200-833$ & $230-1120$ & $200-730$ \\
Bobot gonad (gr) & $0,35-19,05$ & $0,38-27,40$ & $0,3-11,24$ \\
IKG (\%) & $0,16-2,38$ & $0,16-2,45$ & $0,11-1,65$ \\
\hline
\end{tabular}

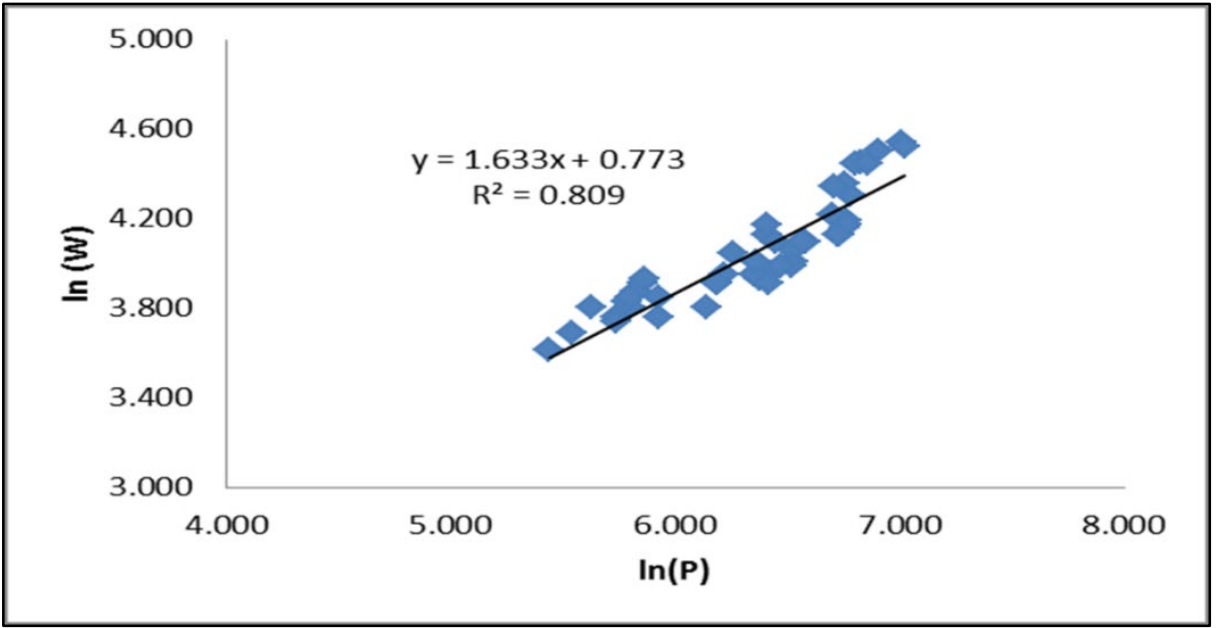

Gambar 7. Hubungan panjang berat sidat dewasa 


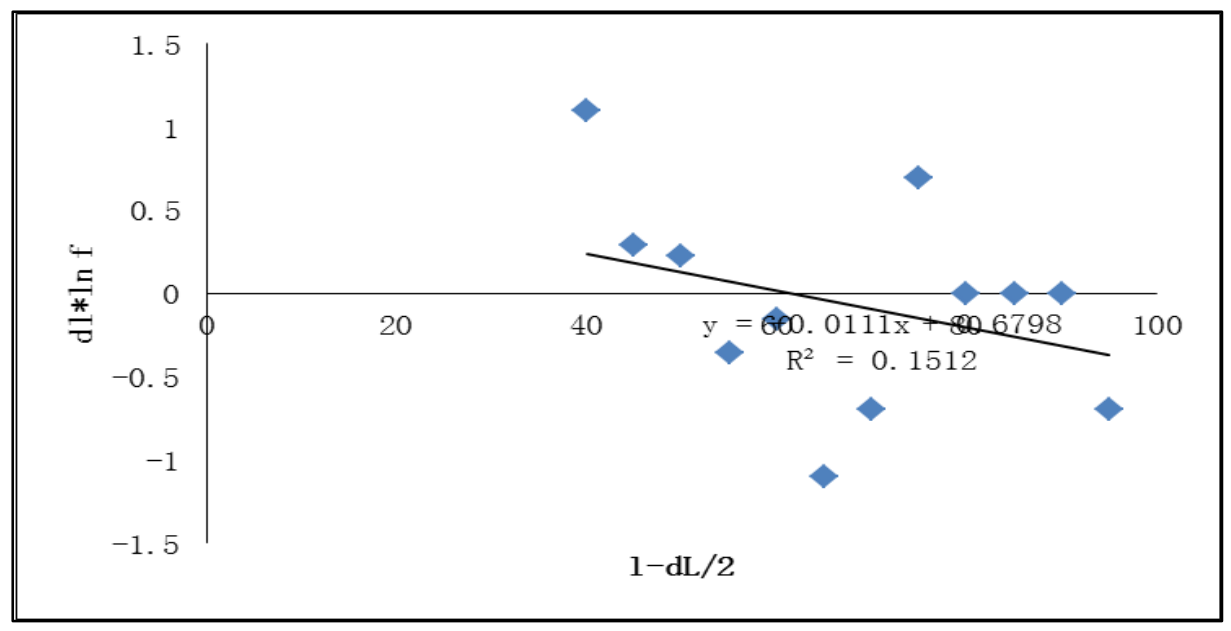

Gambar 8. Grafik pertama kali tertangkap (nilai Lc) pada Sidat dewasa

\section{PEMBAHASAN}

Rangsangan bau air tawar diduga menyebabkan benih sidat berenang menuju pantai dan masuk ke sungai melalui muara. Didukung Muchsin et al., (2003) bahwa benih ikan sidat pada saat memulai perjalanannya masuk ke muara sungai, berwarna bening dan secara bertahap akan berubah menjadi gelap ketika berada di sungai. Benih sidat yang ditangkap di muara sungai Dumoga didominasi A. marmorata dan A. bic. pacifica. Hal ini sesuai dengan pernyataan Sugeha et al. (2010) bahwa A. marmorata dan A. bicolor pacifica cocok sebagai benih untuk kegiatan budidaya sidat, karena kedua spesies tersebut ditemukan dalam jumlah besar sangat bervariasi tanpa pola musiman dan tahunan yang jelas. Gambar 5 menunjukkan hubungan antara jumlah tulang belakang ano-dorsal dan panjang ano-dorsal. Watanabe (2005) dalam diagram pohon filogeni menjelaskan jumlah total tulang belakang A. bicolor pacifica sebanyak 105-111 buah sedangkan jumlah yang diperoleh pada penelitian ini sebanyak 111 buah; untuk jenis A. marmorata sebanyak 103-110 buah, pada penelitian ini diperoleh 105 buah dan jumlah total tulang belakang Anguilla spp. Sebanyak 100-106 buah dan pada penelitian diperoleh 104 buah.

Terjadinya variasi kelimpahan diduga disebabkan oleh kombinasi beberapa faktor yang dapat mempengaruhi penangkapan masing-masing spesies benih sidat, seperti tingkat kelangsungan hidup, waktu dan hasil pemijahan serta perjalanan larva sidat (leptochephalus) mengikuti arus dan proses perubahan ke tahap benih sidat. Hal ini didukung oleh pendapat Sugeha et al., (2008b) bahwa migrasi ikan sidat dipengaruhi oleh faktor terkait iklim. Kelangsungan hidup dan rute migrasi benih sidat dipengaruhi oleh perubahan pola yang disebabkan perubahan iklim.

$$
\text { Ditinjau dari perspektif }
$$

keanekaragaman hayati, keberadaan spesies Anguilla spp. walaupun dalam jumlah kecil dengan nilai anodorsal vertebra $(\mathrm{ADV}) 6-12$ sangat penting untuk memastikan benih sidat yang bertahan hidup saat bermigrasi. Oleh karena itu, setelah didentifikasi, benih sidat kelompok ADV 6-12 dilepas kembali ke muara. Pengamatan variabilitas distribusi jumlah ADV memperkuat kemungkinan bahwa terdapat lebih dari satu spesies dengan jumlah ADV kisaran 6-12 yang diambil dari muara Sungai Dumoga. Selanjutnya, perbedaan ukuran benih sidat ini disebabkan oleh keberadaan dua/lebih spesies dan atau keberadaan benih sidat dari kegiatan pemijahan yang berbeda atau bahkan tempat bertelur yang ditangkap secara bersamaan.

Analisis nisbah kelamin menunjukkan ikan sidat dengan jenis 
kelamin jantan lebih sedikit jumlahnya dari ikan betina dengan perbandingan 0,36 : 0,64 . Hal ini berarti bahwa setiap 1 ekor ikan sidat jantan terdapat 1 ekor ikan sidat betina. Analisis hubungan panjang berat ikan sidat berdasarkan uji $\mathrm{F}$, diketahui pola pertumbuhan ikan sidat secara keseluruhan bersifat allometrik negatif, yakni pertambahan berat tubuh lebih lambat dibandingkan dengan pertambahan panjang tubuh. Pada suatu perairan terdapat perbedaan ukuran dan jumlah dari satu jenis karena perbedaan pola pertumbuhan, perbedaan ukuran pertama kali matang gonad, serta perbedaan masa hidup.

Nilai rata-rata faktor kondisi untuk A. marmorata adalah 0,0024, pada A. bic. pacifica sebesar 0,0026 dan pada Anguilla spp. sebesar 0,0036. Ikan sidat tergolong ikan yang tidak gemuk (pipih) karena faktor kondisinya berkisar antara 0,0024 0,0036 . Hal ini didukung oleh pernyataan Effendie (2002), bahwa untuk ikan yang nilai faktor kondisinya $0-3$, maka ikan tersebut tergolong ikan yang bentuk badannya pipih.

Tingkat perkembangan gonad sidat yang tertangkap di sungai Dumoga berada pada fase yellow eel dan pre silver, belum ditemukan fase silver eel. Hal ini juga didukung oleh hasil perhitungan nilai IKG yang masih berkisar antara 0,11-2,45\%. Kondisi gonad seluruh spesies berada pada tahap intersex, dimana kondisi gonad masih berbentuk benang tipis. Gonad betina berwarna putih krem dan tampak seperti pita berlamela yang lebarnya bervariasi menurut tingkat kematangan gonad, sedangkan gonad jantan berbentuk lobul. Pada stadia juvenil lebar gonad lebih sempit dibanding stadia sub-adult atau presilver. Bobot gonad pada ikan sidat stadia juvenil berkisar antara 0,30-0,38 gr dan pada stadia pre-silver berkisar antara 11,24-27,40 gr. Pada sidat dewasa yang mempunyai bobot tubuh dibawah 300 gr rata-rata bobot gonadnya $<1$ gr dengan ukuran gonad bagian kiri lebih panjang dibanding bagian kanan.
Hasil perhitungan ukuran sidat dewasa pertama kali matang gonad (Lm), yakni didapatkan ukuran panjang 74,74 $\mathrm{cm}$. Ukuran ikan pertama kali matang gonad ikan sidat betina yang berada pada TKG I dapat diartikan dalam kondisi belum matang gonad. Terdapat dua faktor yang mempengaruhi saat pertama kali ikan matang gonad yaitu faktor internal meliputi perbedaan spesies, umur, ukuran, serta sifat fisiologis dari ikan tersebut dan faktor eksternal meliputi makanan, suhu, arus, jenis kelamin dan tempat memijah yang sama. Keberlangsungan aktivitas penangkapan yang dilakukan nelayan sepanjang tahun menimbulkan kekhawatiran punahnya sumberdaya ikan sidat, karena tingginya mortalitas benih sidat pada saat beruaya menuju laut lepas untuk berpijah. Kondisi ini sesuai dengan Sparre and Venema (1998) bahwa jika terlalu sedikit ikan sidat dewasa yang tertangkap, maka stok mengalami lebih tangkap dan tekanan penangkapan tersebut harus dikurangi.

Berdasarkan ukuran ikan pertama kali tertangkap (Lc) dan ukuran ikan pertama kali matang gonad (Lm) sidat yang tertangkap di sungai Dumoga, ikan yang tertangkap dalam kondisi belum matang gonad $(\mathrm{Lc}<\mathrm{Lm})$ dan diperkirakan ikan belum melakukan reproduksi. Hal ini memberikan informasi bahwa pengelolaan sumberdaya ikan sidat di sungai Dumoga kurang baik, karena ikan sidat yang tertangkap dalam kondisi belum matang gonad (Lc $<$ Lm). Pengelolaan penangkapan sidat yang baik apabila ikan yang tertangkap 90\% telah melakukan reproduksi atau mencapai ukuran optimum, sehingga proses pengambilan biomassa yang baru tetap berjalan dan kondisi stok ikan sidat akan tetap stabil. Hal ini didukung oleh Froese (2003) yang menyatakan bahwa lebih tangkap dapat dicegah dengan mengikuti ketentuan aturan, yaitu menangkap ikan yang telah mencapai ukuran panjang optimal, dimana ukuran ini biasanya ikan sedikit lebih besar daripada ukuran ikan pertama kali matang 
gonad, sehingga ikan mendapatkan kesempatan untuk memijah sebelum tertangkap.

\section{KESIMPULAN}

Panjang sidat dewasa rata-rata $58,92 \mathrm{~cm}$ pada A. marmorata (IKG 1,57$2,90 \%) ; 54,2 \mathrm{~cm}$ pada A. bicolor pacifica (IKG $1,27-2,79 \%$ ) dan $52,32 \mathrm{~cm}$ pada Anguilla spp (IKG 0,97-2,50\%). Ikan sidat ukuran 30-90 cm mempunyai kisaran TKG pada tingkatan yang belum teridentifikasi dan belum berkembang ke tahap matang gonad.

\section{DAFTAR PUSTAKA}

Effendie, M.I. (2002). Biologi Perikanan. Yayasan Pustaka Nusantara, Yogyakarta. Hlm. 163.

Froese, R. 2003. Keep it Simple: three indicators to deal with overfishing. Institute of Marine Sciences, Du“sternbrooker, Germany.

Kusuma, N. D. (2016). Kearifan Lokal Dari Tano Batak ke Maluku: Pemanfaatan Ikan Sidat (Anguilla spp.) Berbasis Kearifan Lokal di Kabupaten Minahasa Selatan dan Kabupaten Bolaang Mongondow. CV. Rajawali Corporation. Jakarta.

Kusuma N. D., Herawati, E.Y., dan Sambah, A.B. (2018). Type Composition Of Eel Seed (Anguilla Spp.) In Dumoga Creek, Bolaang Mongondow. Russian Journal of Agricultural and Socio-Economic Sciences. RJOAS 8(80). DOI https://doi.org/10.18551/rjoas.201808.48 .

Muchsin, I., Zairion and Samliok, N. (2003). Upaya Meningkatkan Keberhasilan Migrasi Anadromous Katadromous Ikan Sidat (Anguilla spp.) di Sungai Poso Kabupaten Poso, Sulawesi Tengah. Laporan Akhir RUT VIII. Lembaga Penelitian IPB. 22 p.

Sparre, P. and Venema, S.C. (1998). Introduction to Tropical Fish Stock
Assessment, Part I: Manual. FAO Fisheries Technical Paper, 306, 1.

Sugeha H.Y, F Tantu, S Wouthuyzen, and K. Tsukamoto. (2008b). Inshore Migration of the Tropical Anguillid Glass Eels in the Palu River Estuary, Western Sulawesi Island Indonesia. Proceedings of the World Fisheries Congress 2008, in Yokohama, Japan.

Sugeha H.Y and Arai, T. (2010). Contrasting Morphology, Genetic, and Recruitment Season of Anguilla marmorata Glass Eels from Northern, Western, and Central Sulawesi Island, Indonesia. Ilmu Kelautan Vol. 1. ISSN 0853 - 7291.

Serdiati, N., Samliok, N., Abigail, M., dan Deddy, W. (2013). Species Composition of Glass Eels (Anguilla spp.) Recruiting to the Palu River, Central Sulawesi. Jurnal Iktiologi Indonesia, 13(2):109-123.

Watanabe S, Aoyama J, Nishida M, and Tsukamoto K, (2005). Evaluation of the Population Structure of Anguilla bicolor bicolor using total number of vertebrae and the mtDNAcontrol region. Coastal Marine Science. (29): 165-9.

Widyasari R.A.H.E. (2013). Desain Pengembangan Industri Perikanan Sidat Indonesia Anguilla spp. Berkelanjutan di Palabuhan Ratu, Kabupaten Sukabumi Provinsi Jawa Barat. (Disertasi). Bogor (ID): Institut Pertanian Bogor. 